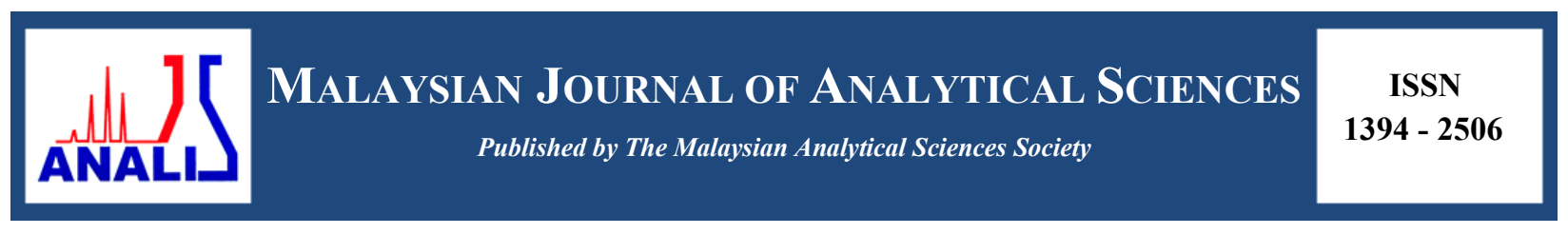

\title{
EFFECT OF BUFFER COMPOSITION ON THE ANALYSIS OF LIPOPOLYSACCHARIDES FROM Escherichia coli 055:B5 AND UT189 BY CAPILLARY ELECTROPHORESIS WITH DIRECT UV DETECTION
}

\author{
(Kesan Komposisi Penimbal ke atas Analisis Lipopolisakarida dari Escherichia coli 055:B5 dan \\ UT189 oleh Elektroforesis Kapilari dengan Pengesan UV) \\ Fun Man Fung ${ }^{1}$, Min $\mathrm{Su}^{1}$, Sam Fong Yau $\mathrm{Li}^{1,2 *}$ \\ ${ }^{1}$ Department of Chemistry, \\ National University of Singapore, 3 Science Drive 3, Singapore 117543, Singapore \\ ${ }^{2}$ Singapore-Peking-Oxford Research Enterprise (SPORE) Programme, \\ NUS Environmental Research Institute (NERI) \#02-01, T-Lab Building (TL), 5 a Engineering Drive1 1, Singapore 117411, \\ Singapore \\ *Corresponding author: chmlifys@nus.edu.sg
}

Received: 7 November 2016; Accepted: 18 September 2017

\begin{abstract}
Endotoxins are known to many as bacterial toxins. Conventional analysis of endotoxins by capillary electrophoresis-mass spectrometry is laborious and time consuming. A faster capillary electrophoresis method using direct ultraviolet (UV) detection was performed to analyze endotoxins isolated from Escherichia coli (E. coli) 055:B5 and UT189. In this study, we compared different running buffers and buffer additives to examine the effects of each on the electropherograms obtained. The optimum buffer system was then used to analyze of lipopolysaccharides (LPS) signals from the bacteria E. coli 055:B5 (source strain CDC 1644-70), E. coli K-235 (source strain ATCC 13027) and Klebsiella pneumoniae (source strain ATCC 15380). The data generated for each variant peak showed very good precision and high reproducibility for migration time with percentage RSD values of $\leq 1.2 \%(n=3)$. Similarly, the percentage RSD for peak areas were $\leq 5.3 \%(n=3)$ across the three LPS.
\end{abstract}

Keywords: capillary electrophoresis, direct UV, endotoxin, lipopolysaccharides, buffer

\section{Abstrak}

Endotoksin diketahui sebagai bakteria yang berbahaya. Kaedah konvensional bagi endotoksin oleh elektroforesis kapilari-jisim spektrometri adalah bersifat rumit dan memerlukan tempoh masa yang panjang. Kaedah elektroforesis kapilari yang pantas menggunakan pengesan ultralembayung telah dijalankan untuk menganalisa endotoksin yang dipisahkan dari Escherichia coli (E. coli) 055:B5 and UT189. Dalam kajian ini, larutan penimbal yang berbeza telah diuji dan penambahan penimbal dilakukan untuk mengkaji kesan bagi setiap elektropherogram yang terhasil. Sistem penimbal yang optimum kemudian digunakan untuk menganalisa respon lipopolisakarida (LPS) dari bakteria E. coli 055:B5 (sumber strain CDC 1644-70), E. coli K-235 (sumber strain ATCC 13027) and Klebsiella pneumoniae (sumber strain ATCC 15380). Data yang terhasil bagi puncak setiap varian menunjukkan ia adalah jitu dan kebolehulangan yang tinggi bagi masa pemindahan dengan nilai peratus $\mathrm{RSD}$ ialah $\leq 1.2 \%(\mathrm{n}=$ 3). Begitu juga, peratus RSD bagi luas - luas puncak ketiga - tiga LPS ialah $\leq 5.3 \%(n=3)$.

Kata kunci: elektroforesis kapilari, UV langsung, endotoksin, lipopolisakarida, penimbal 


\section{Fung et al: EFFECT OF BUFFER COMPOSITION ON THE ANALYSIS OF LIPOPOLYSACCHARIDES FROM Escherichia coli 055:B5 AND UT189 BY CAPILLARY ELECTROPHORESIS WITH DIRECT UV DETECTION}

\section{Introduction}

Endotoxins are of great relevance in today's research because most layman would believe that killing bacteria by boiling water alone would ensure toxin-free water. However, endotoxins are released by bacteria after lysis by cell death at high temperature. Endotoxins causes inflammatory reactions and sepsis which can be fatal [1]. Since they are found in high concentrations in wastewater from industries coupled with less than optimal waste treatment [2, $3]$, the efficiency for the secondary treatment of industry effluents must be addressed.

Endotoxins are found in the cell wall of Gram-negative bacteria. Essentially, endotoxins are major components of the exterior of the outer membrane of the Gram-negative cell wall. Endotoxins are lipopolysaccharides (LPS) and are known to many as bacterial toxins. They are hydrophilic and face outward from the cell membrane and into the medium in which the bacteria is growing [4]. LPS contains major antigens of the bacteria and is the most important target of Gram-negative bacteria for the immune response [5]. Each LPS molecule is unique to a particular Gramnegative bacteria and exhibits much variation in its structure [6] an example shown in Figure 1.

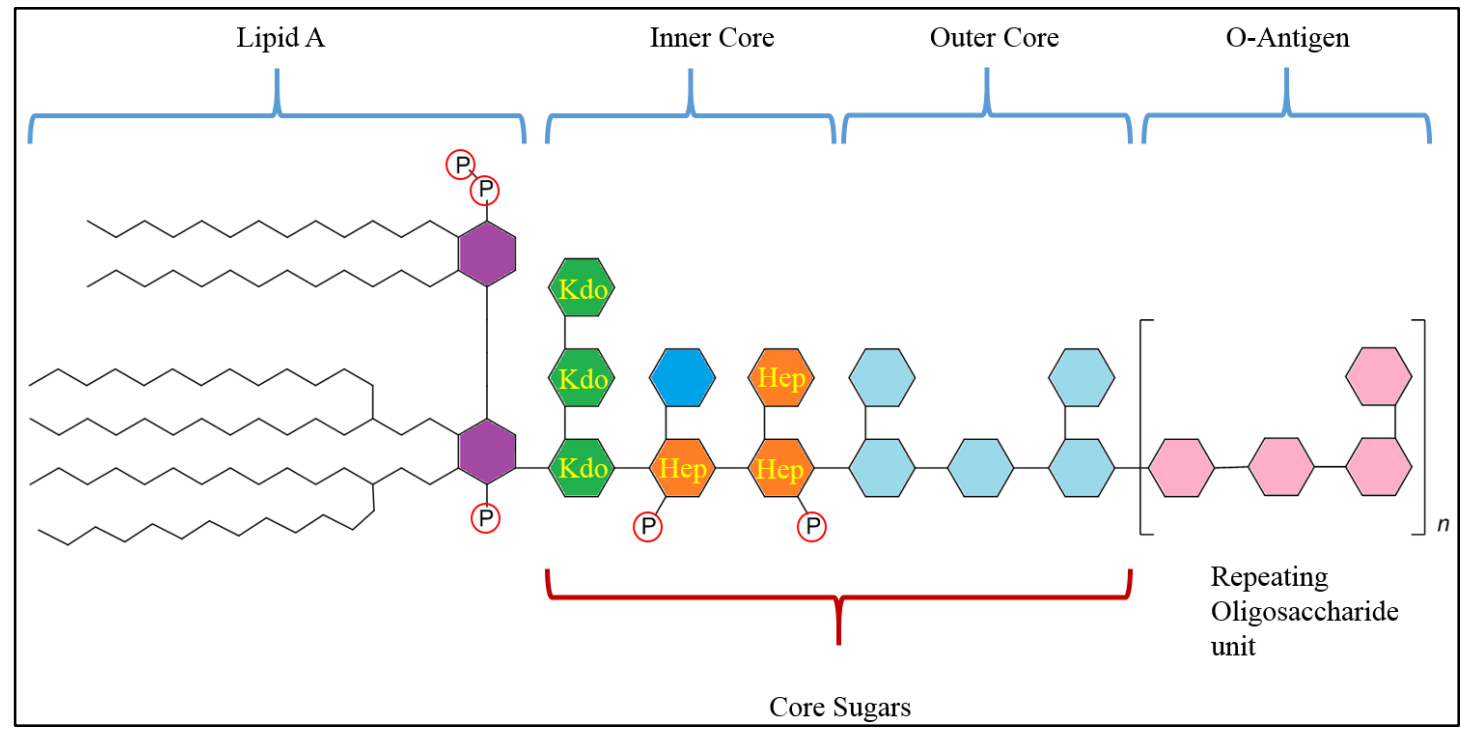

Figure 1. The general structure of lipopolysaccharide molecule, segmented primarily into lipid A, inner core, outer core, and $O$-antigen

Previous research has shown that the heterogeneity of different LPS mixtures enable scientists to distinguish them via mass spectrometric detection [7]. Their differences in molecular weight, size, and connectivity of the branched chains allow the combined use of both online and offline separation techniques [8]. Such distinct structural differences also allow the LPS to be separated via high-performance capillary electrophoresis (CE) for further analysis, as performed by Restaino et al. [9] on the E. coli K4 cell surface polysaccharides. LPS from E. coli 055:B5 has also been analyzed by CE-UV. However, in the study, only one surfactant, sodium dodecyl sulfate (SDS) was experimented in the running buffer [10]. LPS, being amphiphilic molecules, are prone to aggregation of the repeating oligosaccharide units in the $O$-antigen segment $[11,12]$. Without the presence of surfactants, it is perceivable that the LPS form micelles and acquire lower solubility, giving rise to precipitates and lower reproducibility of electropherograms. Thus, it is believed that the migration behavior of LPS will alter when different surfactants are used, depending on the main buffering system. Although work has been performed on the investigation of various concentration of SDS in selected LPS electropherogram [13 - 16], no study has reported the effect of surfactants and buffering system on the LPS extracted from E. coli K-235, E. Coli UT189 and Klebsiella pneumoniae. In this paper, the study of different surfactants and buffering system for the optimization of LPS separation by $\mathrm{CE}$ is reported. 


\section{Chemicals}

\section{Materials and Methods}

Sodium dodecyl sulfate (SDS), sodium borate, sodium hydroxide were obtained from Merck (Darmstadt, Germany). Buffers were prepared with ultrapure water obtained from Millipore equipment (Millipore, Bedford, MA, USA). Commercially prepared tris(hydroxymethyl)aminomethane (Tris), boric acid, disodium ethylenediaminetetraacetic acid (EDTA) buffer was purchased from Bio-Rad laboratories (Singapore). Poly(ethylene)oxide (PEO, Mr 600 000) was purchased from Sigma-Aldrich (Singapore). 1,4-diaminobutane (DAB) was purchased from Fluka (Münster, Germany).

\section{Bacteria strains and endotoxins preparation}

Lyophilized lipopolysaccharides powders from E. coli 055:B5 (Lot \#025M4040V) purified by gel-filtration chromatography, E-Toxate ${ }^{\mathrm{TM}}$ Endotoxin standard, E. coli K-235 purified by gel-filtration chromatography, Klebsiella pneumoniae purified by phenol extraction were purchased from Sigma Aldrich. E. Coli UT189 was donated by Bau Yi Woo of Department of Chemistry, National University of Singapore.

LPS from E. Coli UT189 was prepared by the following procedure: To obtain pure and lyophilized LPS we used the hot phenol-water procedure according to Westphal et al. [17]. Crude LPS was recovered from the combined aqueous phase and subjected to further purification as reported in the conventional method. Purified LPS samples were lyophilized for $\sim 18 \mathrm{~h}$ to yield a white-fluffy powder that was used for analysis.

\section{Instrumentation}

All electrophoretic separations were performed on a Beckman Coulter PA 800 plus system (AB Sciex, USA), using photodiode array (PDA) absorbance detection set at $195 \mathrm{~nm}$. Uncoated fused silica capillaries $(50 \mathrm{~m} \mathrm{ID} \times 360 \mathrm{~m}$ OD) were purchased from Polymicro Technologies Inc. (Phoenix, AZ, USA). New capillaries were flushed with 1M $\mathrm{NaOH}$, ultrapure water and background electrolyte (BGE) for 10 minutes each. Preconditioning was performed by flushing with BGE for 3 minutes. The Beckman Coulter's 32 Karat $^{\mathrm{TM}}$ version 9.1 software was used for data analysis, data acquisition and peak integration.

\section{CE-UV experiments}

For CE-UV experiments the capillaries were cut to a length of $39 \mathrm{~cm}$. For each capillary, a $0.30 \mathrm{~cm}$ transparent window was created by burning the capillary $10 \mathrm{~cm}$ from one of the ends. The capillary was burnt with a general butane lighter and the size of the window was consistently maintained by wrapping the capillary with an Aluminum foil with at $0.30 \mathrm{~cm}$ aperture. Detection was done using a CE photodiode array detectors (PDA) equipped with a deuterium lamp. The length of this irradiation window was $1 \mathrm{~cm}$ and the distance between lamp and capillary about $2 \mathrm{~cm}$. All the measurements were carried out at $16^{\circ} \mathrm{C}$ with the applied voltage set at $30 \mathrm{kV}$. All measurements were carried out at least three times. The LPS was dissolved in the BGE to make up a concentration of $5.0 \mathrm{mg} / \mathrm{mL}$. The various buffering systems applied in this report are summarized in Table 1.

Table 1. Different running buffers used in CE-UV analysis of intact LPSs.

\begin{tabular}{lllll}
\hline Number & Buffer System/ BGE & Concentration & pH & Reference \\
\hline 1 & $\mathrm{SDS} / \mathrm{Na}_{2} \mathrm{~B}_{4} \mathrm{O}_{7} / \mathrm{Na}_{2} \mathrm{HPO}_{4}$ & $40 \mathrm{mM} / 10 \mathrm{mM} / 40 \mathrm{mM}$ & 9.00 & {$[9]$} \\
2 & $\mathrm{SDS} / \mathrm{Na}_{2} \mathrm{~B}_{4} \mathrm{O}_{7}$ & $40 \mathrm{mM} / 10 \mathrm{mM}$ & 9.22 & This study \\
3 & Tris/Borate/EDTA/PEO & $3.94 \mathrm{mM} / 0.56 \mathrm{mM} / 0.013 \mathrm{mM} / 0.02 \%$ & 9.14 & {$[18]$} \\
4 & Tris/Borate/EDTA & $445 \mathrm{mM} / 445 \mathrm{mM} / 10 \mathrm{mM}$ & 8.45 & This study \\
5 & Tris/Borate/EDTA/PEO & $445 \mathrm{mM} / 445 \mathrm{mM} / 10 \mathrm{mM} / 0.02 \%$ & 7.77 & This study \\
6 & $\mathrm{Na}_{2} \mathrm{~B}_{4} \mathrm{O}_{7}$ & $50 \mathrm{mM}$ & 9.40 & {$[19]$} \\
7 & $\mathrm{Na}_{2} \mathrm{~B}_{4} \mathrm{O}_{7} / \mathrm{DAB}$ & $50 \mathrm{mM} / 10 \mathrm{mM}$ & 9.11 & {$[20]$} \\
8 & Tricine & $50 \mathrm{mM}$ & 5.21 & This study \\
\hline
\end{tabular}




\section{Fung et al: EFFECT OF BUFFER COMPOSITION ON THE ANALYSIS OF LIPOPOLYSACCHARIDES FROM Escherichia coli 055:B5 AND UT189 BY CAPILLARY ELECTROPHORESIS WITH DIRECT UV DETECTION}

\section{Results and Discussion}

The LPS isolated from E. coli 055:B5 and UT189 were analyzed with the buffering systems consisting of SDS/ $\mathrm{Na}_{2} \mathrm{~B}_{4} \mathrm{O}_{7} / \mathrm{Na}_{2} \mathrm{HPO}_{4}(40 \mathrm{mM} / 10 \mathrm{mM} / 40 \mathrm{mM}, \mathrm{pH} 9.0)$ as reported by Restaino et al., although the electropherograms obtained with this buffering system could not ascertain the location of a definitive set of LPS signals, unlike the success reported for E. coli K4 [9]. In the electropherograms shown in Figure 2, only that of E. coli 055:B5 marginally provides the signature twin signals at migration times of around 6.83 minutes.
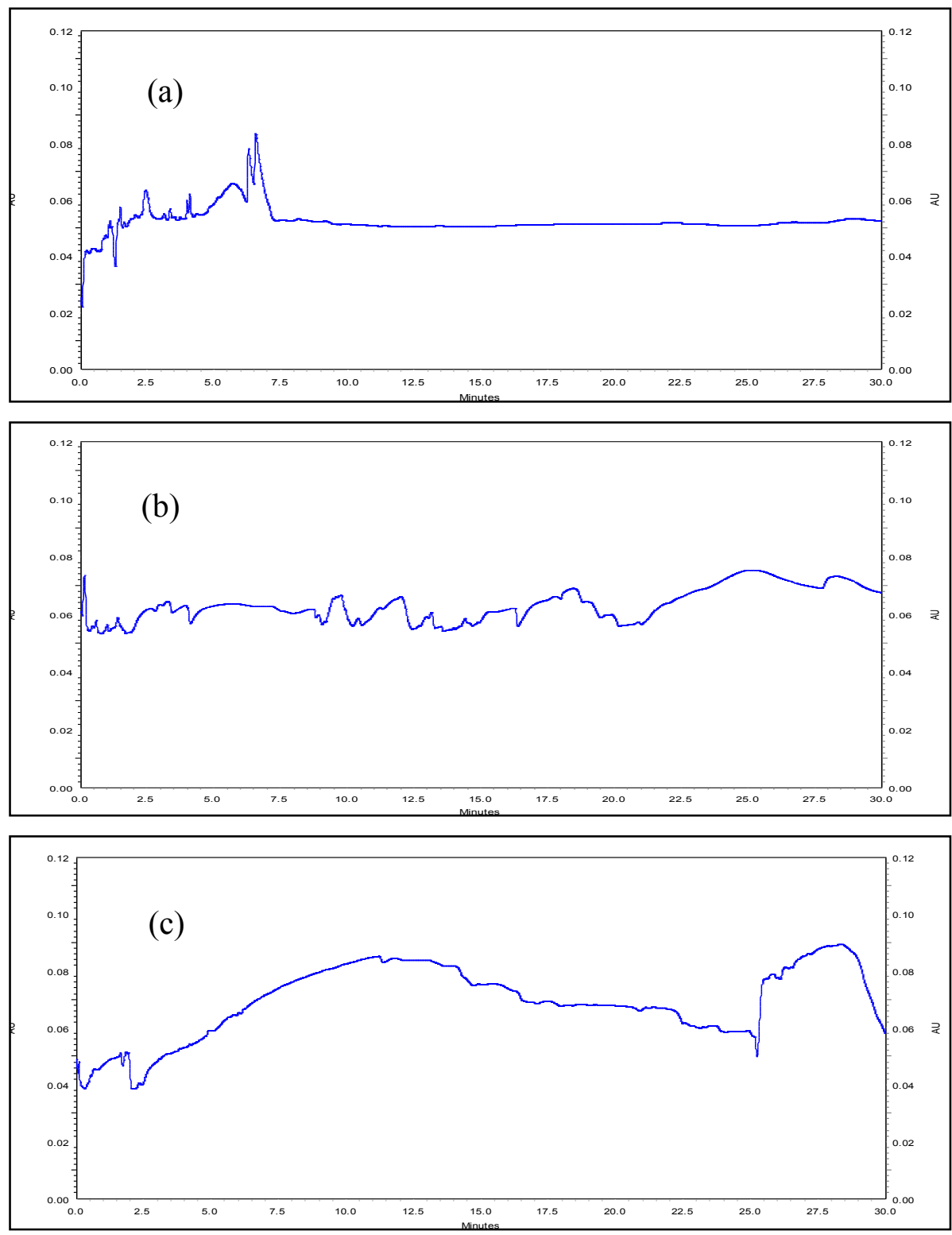

Figure 2. CE-UV electropherograms of lipopolysaccharides from Gram-negative bacteria (A) 055:B5; (B) EToxate ${ }^{\mathrm{TM}}$; (C) UT189. Running buffer: SDS/ $\mathrm{Na}_{2} \mathrm{~B}_{4} \mathrm{O}_{7} / \mathrm{Na}_{2} \mathrm{HPO}_{4}(40 \mathrm{mM} / 10 \mathrm{mM} / 40 \mathrm{mM}$, pH 9.0). Applied voltage $=30 \mathrm{kV}$; injection time $=5 \mathrm{~s}$. Capillary dimensions are indicated in experimental section

One of the reasons why the previous buffer system could not give a distinct signal in the electropherograms of LPS E-Toxate ${ }^{\mathrm{TM}}$ and UT189 is the solubility of the LPS in the buffer. As mentioned in the introduction, different strains 
of bacteria vary in molecular size, and the number of repeat oligosaccharide units ( $n$ value) in the $O$-antigen segment of the structure. The higher the $n$ value, the more likely it is for the oligosaccharide chain to form multiple intramolecular hydrogen bonds (H-bonds) within the $O$-antigen chain, creating an aggregate which may decrease its solubility in selected buffers. The surfactant used according to Restaino et al. was SDS [9], which is an anionic surfactant that increases the overall ionic strength of the buffer. A non-ionic neutral surfactant, polyethylene oxide (PEO), was used as a replacement instead on LPS E-Toxate ${ }^{\mathrm{TM}}$ and UT189, by Yu et al. using Tris/ $\mathrm{Na}_{2} \mathrm{~B}_{4} \mathrm{O}_{7} /$ EDTA/PEO (3.94 mM/0.56 mM/0.013 mM/0.02\%, $\mathrm{pH} \mathrm{9.14)} \mathrm{as} \mathrm{the} \mathrm{buffer} \mathrm{system} \mathrm{[18].} \mathrm{At} \mathrm{this} \mathrm{pH}$, all the ionizable functional groups in the LPS would have been deprotonated, and they carry uniformly negatively charges, giving rise to an increase in charge density, and a more consistent electrophoretic mobility of the LPS. In Figure 3, both electropherograms exhibit the detected LPS signals: at 1.52 minutes for E-Toxate ${ }^{\mathrm{TM}}$ and 2.31 minutes for UT189.
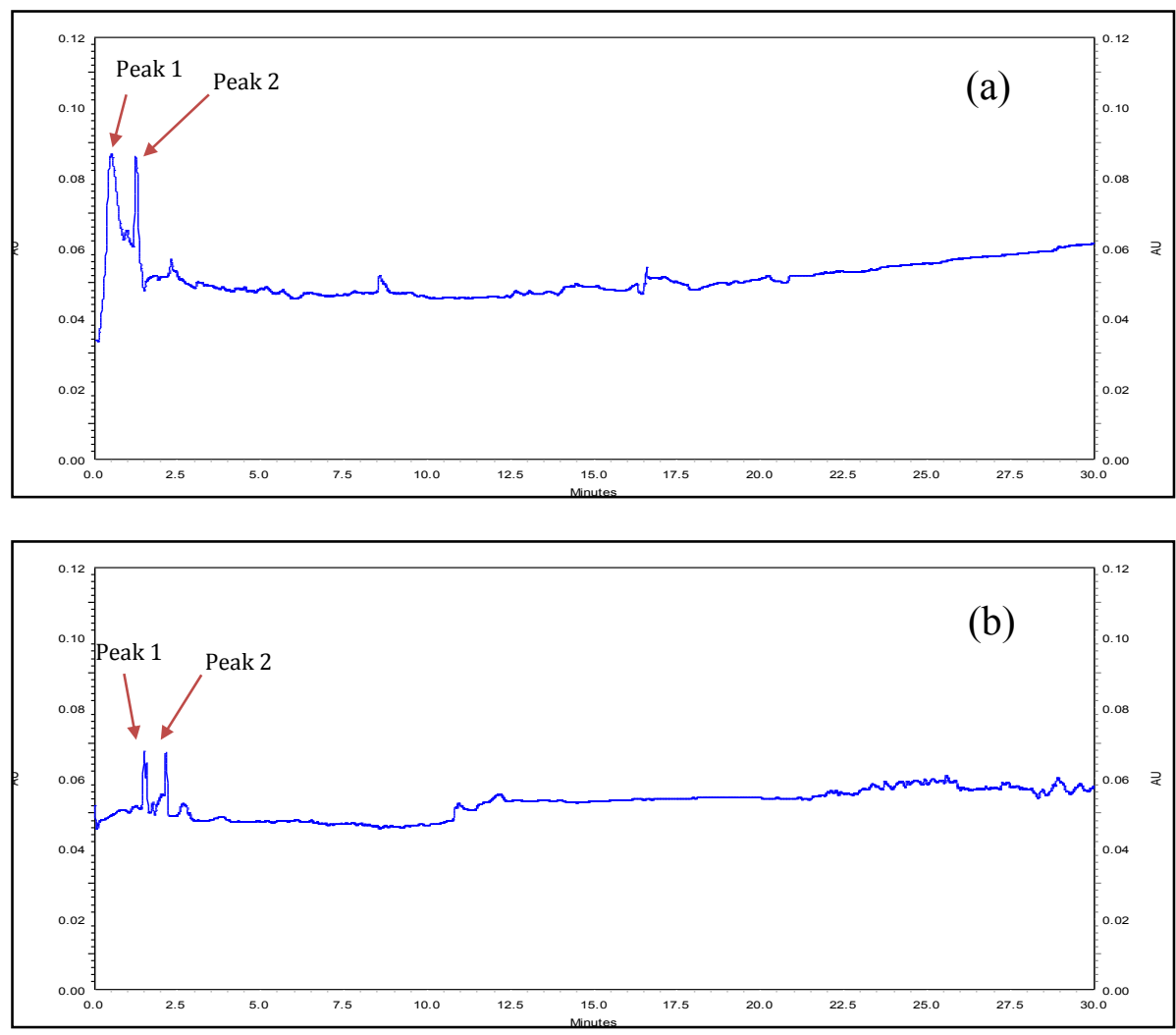

Figure 3. CE-UV electropherograms of lipopolysaccharides from Gram-negative bacteria (A) E-Toxate ${ }^{\mathrm{TM}}$; (B) UT189. Running buffer: Tris/ $\mathrm{Na}_{2} \mathrm{~B}_{4} \mathrm{O}_{7} /$ EDTA/PEO (3.94 mM/0.56 mM/0.013 mM/0.02\%, pH 9.14). Applied voltage $=30 \mathrm{kV}$; injection time $=5 \mathrm{~s}$. All other conditions are the same as stated in the experimental section.

The use of PEO in place of SDS has allowed the detection of LPS signals which were previously not seen. However, these LPS signals have relatively short migration times, which means that the use of an electroosmotic flow (EOF) marker will not be accurate. The EOF should preferably produce a signal that has a lower migration time than that of the analytes. This EOF marker signal will have the same relative differences in migration time to the respective analyte signals. Having low migration times for the analytes in this case would mean lower accuracy when comparing the mobilities of the various LPS. The three LPS were then analyzed using a modified buffering system by the use of a commercially purchased Tris/Borate/EDTA $(445 \mathrm{mM} / 445 \mathrm{mM} / 10 \mathrm{mM}, \mathrm{pH} 7.77)$ buffer and the addition of PEO $(0.02 \%)$. This change in the concentration of the ions and the $\mathrm{pH}$ provided the desired effect of delaying the migration time of the LPS signals, as seen in Figure 4. Comparing the electropherograms of the E- 
Fung et al: EFFECT OF BUFFER COMPOSITION ON THE ANALYSIS OF LIPOPOLYSACCHARIDES

FROM Escherichia coli 055:B5 AND UT189 BY CAPILLARY ELECTROPHORESIS WITH

DIRECT UV DETECTION

Toxate ${ }^{\mathrm{TM}}$, the new buffering system with almost 900 times increase in sodium borate concentration increases the migration time from 1.52 minutes to 2.41 minutes. Likewise for UT189, the migration time increases from 2.31 minutes to 2.92 minutes.
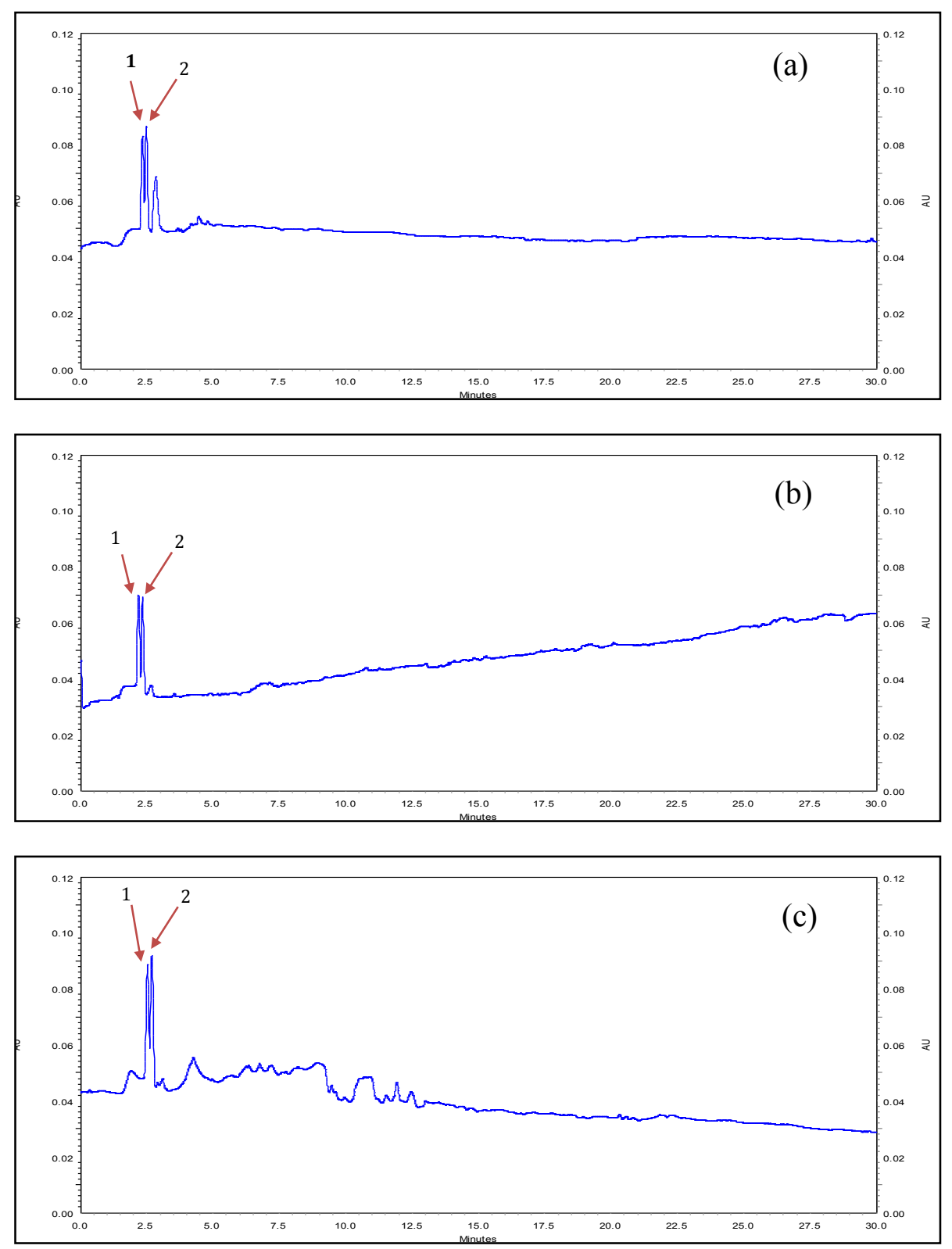

Figure 4. CE-UV electropherograms of lipopolysaccharides from Gram-negative bacteria (A) 055:B5; (B) EToxate ${ }^{\mathrm{TM}}$; (C) UT189. Running buffer: Tris/ $\mathrm{Na}_{2} \mathrm{~B}_{4} \mathrm{O}_{7} /$ EDTA/PEO $(445 \mathrm{mM} / 445 \mathrm{mM} / 10 \mathrm{mM} / 0.02 \%$, pH 7.77). Applied voltage $=30 \mathrm{kV}$; injection time $=5 \mathrm{~s}$. Capillary dimensions are indicated in experimental section

Although the migration times were prolonged slightly after increasing the Tris $/ \mathrm{Na}_{2} \mathrm{~B}_{4} \mathrm{O}_{7} / \mathrm{EDTA}$ concentration, we believed that this can be increased further. The same LPS were subsequently analyzed with the buffer system consisting of Tris/Borate/EDTA ( $445 \mathrm{mM} / 445 \mathrm{mM} / 10 \mathrm{mM}, \mathrm{pH} 8.45)$. Without the addition of PEO into this buffer 
system, the migration times for all three LPS electropherograms showed marked increment. As shown in Figure 5, the migration times for 055:B5, E-Toxate ${ }^{\mathrm{TM}}$ and UT189 increased to 7.10 minute, 6.48 minute and 11.22 minute respectively. The pair of distinctive peaks at migration times of $6.07( \pm 0.10)$ and $6.48( \pm 0.10)$ minutes could be used to identify the presence of E-Toxate ${ }^{\mathrm{TM}}$ LPS. These twin peaks showed maximum absorbance at $195 \mathrm{~nm}$ in the 3D CE-UV plot (Figure 6).
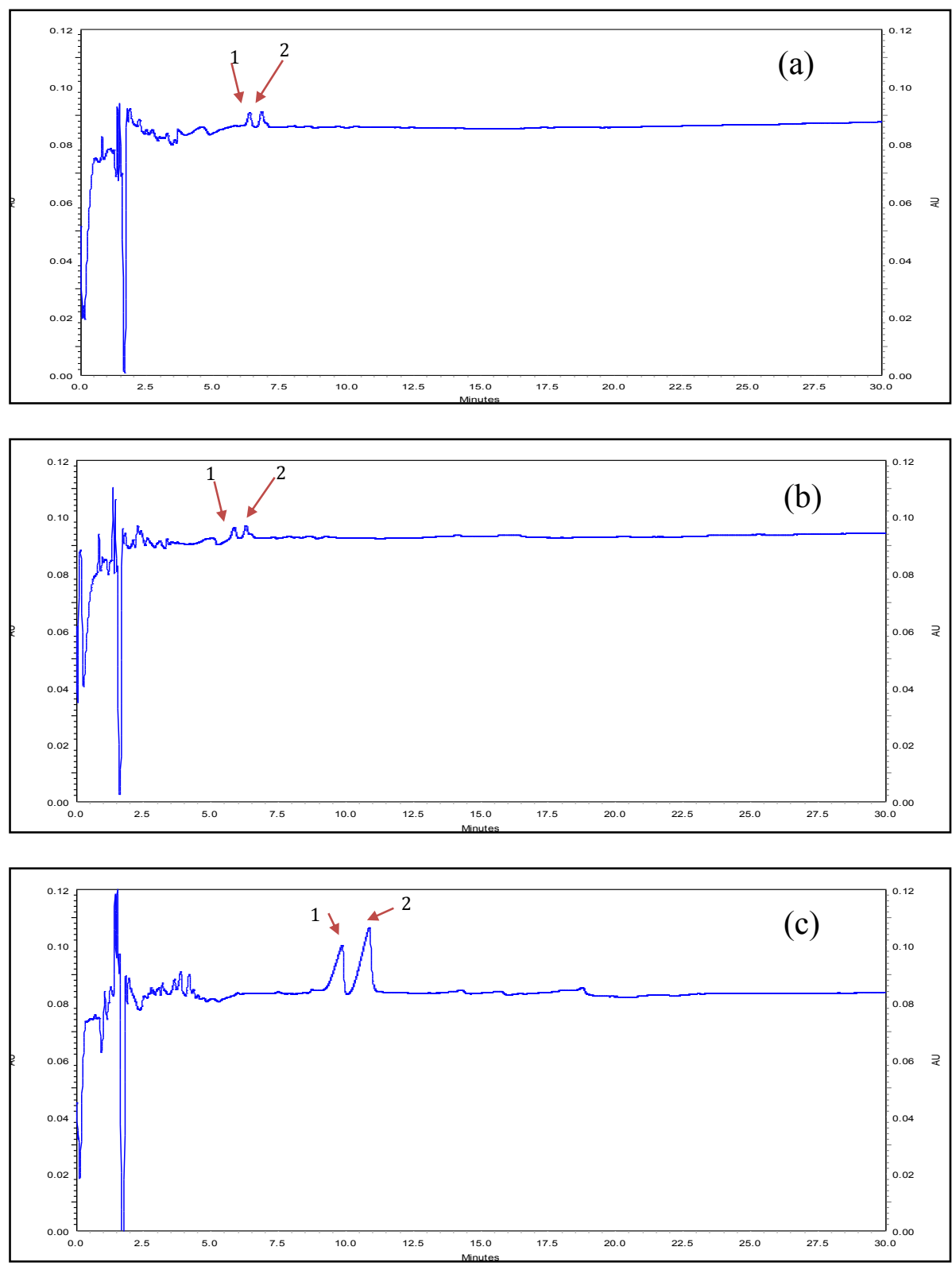

Figure 5. CE-UV electropherograms of lipopolysaccharides from Gram-negative bacteria (A) 055:B5; (B) EToxate ${ }^{\mathrm{TM}}$; (C) UT189. Running buffer: Tris/ $\mathrm{Na}_{2} \mathrm{~B}_{4} \mathrm{O}_{7} /$ EDTA (445 mM/445 mM/10 mM, pH 8.45). Applied voltage $=30 \mathrm{kV}$; injection time $=5 \mathrm{~s}$. Capillary dimensions are indicated in experimental section 
Fung et al: EFFECT OF BUFFER COMPOSITION ON THE ANALYSIS OF LIPOPOLYSACCHARIDES

FROM Escherichia coli 055:B5 AND UT189 BY CAPILLARY ELECTROPHORESIS WITH

DIRECT UV DETECTION

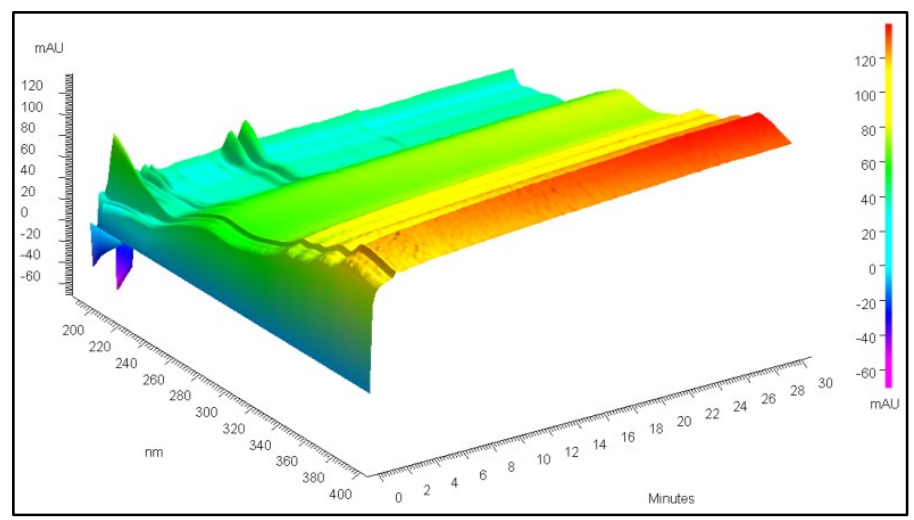

Figure 6. 3-D plot of electropherograms of E-Toxate ${ }^{\mathrm{TM}}$ LPS showing the maximum absorbance at $195 \mathrm{~nm}$. Separation condition: buffer - Tris/ $\mathrm{Na}_{2} \mathrm{~B}_{4} \mathrm{O}_{7} /$ EDTA $445 \mathrm{mM} / 445 \mathrm{mM} / 10 \mathrm{mM} ; \mathrm{pH}$ 8.3. Applied voltage $=30 \mathrm{kV}$; injection time $=5 \mathrm{~s}$. All other conditions are the same as stated in the experimental section

Venter et al. optimized the running buffer for LPS extracted from E. coli (source strain ATCC 25922) using $50 \mathrm{mM}$ borate [19]. In our study, LPS E-Toxate ${ }^{\mathrm{TM}}$ was analyzed to check the effect of another surfactant, 1,4diaminobutane (DAB), on the migration profile of the LPS. In Figure 7, results showed that after the addition of DAB the LPS signals are better resolved. The migration time increased from 1.52 minute to 8.53 minutes after the addition of DAB. This enhancement of resolution can be attributed to the shorter hydrophilic chain of DAB which allows greater interaction and promotes dispersion effect in the oligosaccharides chain of the LPS. Unlike PEO, $\mathrm{DAB}$ does not polymerize and form a macromolecule that can interfere with the dispersion of the repeating polysaccharide unit. With the increased London dispersion forces derived from a non-polar macromolecule, PEO exerts less interaction with the oligosaccharides, whose main intermolecular forces of attraction is H-bond. This undesired incompatible effect contrasts with that of DAB which interacts non-covalently primarily by H-bond, and as such it will minimize the aggregation of the sugar units at the $O$-polysaccharide segment. Unfortunately, the addition of DAB causes a significant impedance to the EOF, which results in longer analysis time.

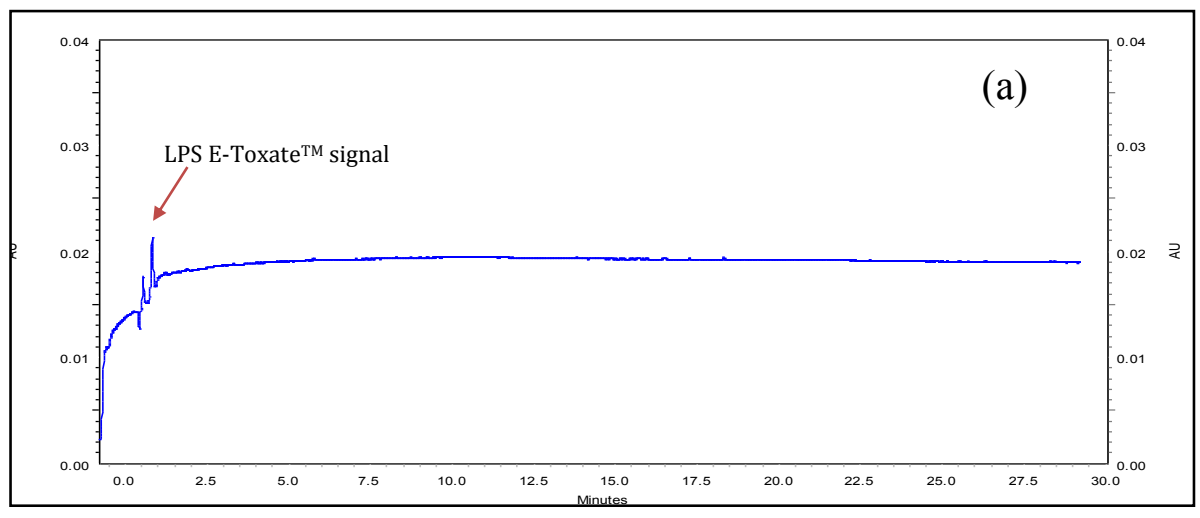




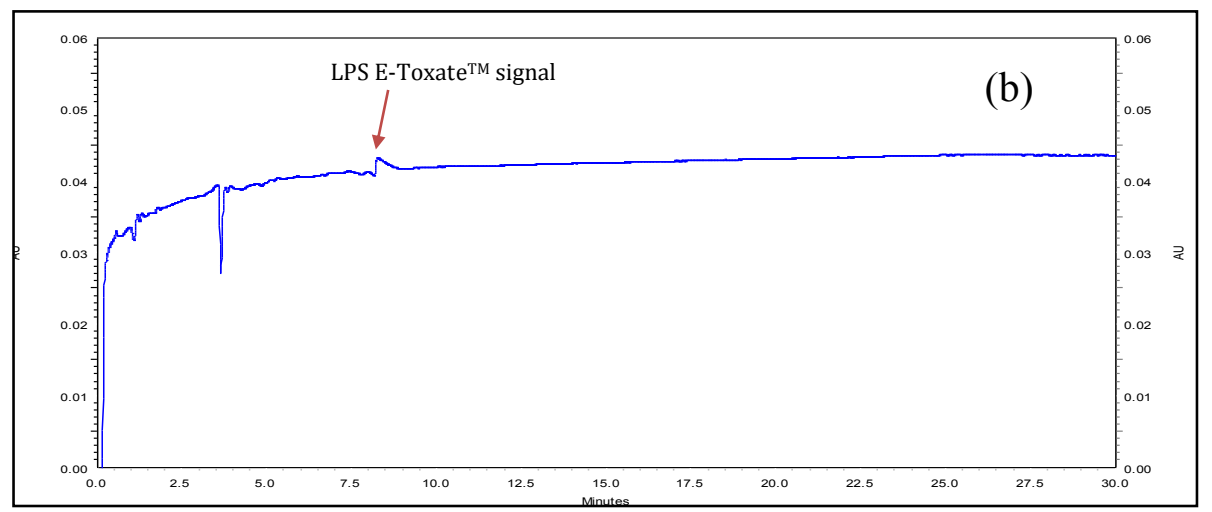

Figure 7. CE-UV electropherograms of lipopolysaccharides from E-Toxate ${ }^{\mathrm{TM}}$ (A) Running buffer: $\mathrm{Na}_{2} \mathrm{~B}_{4} \mathrm{O}_{7}(50$ $\mathrm{mM}$, pH 9.40); (B) Running buffer: $\mathrm{Na}_{2} \mathrm{~B}_{4} \mathrm{O}_{7} / \mathrm{DAB}(50 \mathrm{mM} / 10 \mathrm{mM}$, pH 9.11). Applied voltage $=30 \mathrm{kV}$; injection time $=5 \mathrm{~s}$. All other conditions are the same as stated in the experimental section

In order to ascertain if SDS works better than DAB in borate buffer system, LPS extracted from E. coli 055:B5, EToxate $^{\mathrm{TM}}$ and Klebsiella pneumoniae were analyzed by using SDS/ $\mathrm{Na}_{2} \mathrm{~B}_{4} \mathrm{O}_{7}(40 \mathrm{mM} / 10 \mathrm{mM}, \mathrm{pH} 9.22)$. Figure 8 shows that the baselines for both electropherograms are more stable and exhibit a higher signal-to-noise ratio than that using $\mathrm{DAB}$ as the surfactant.
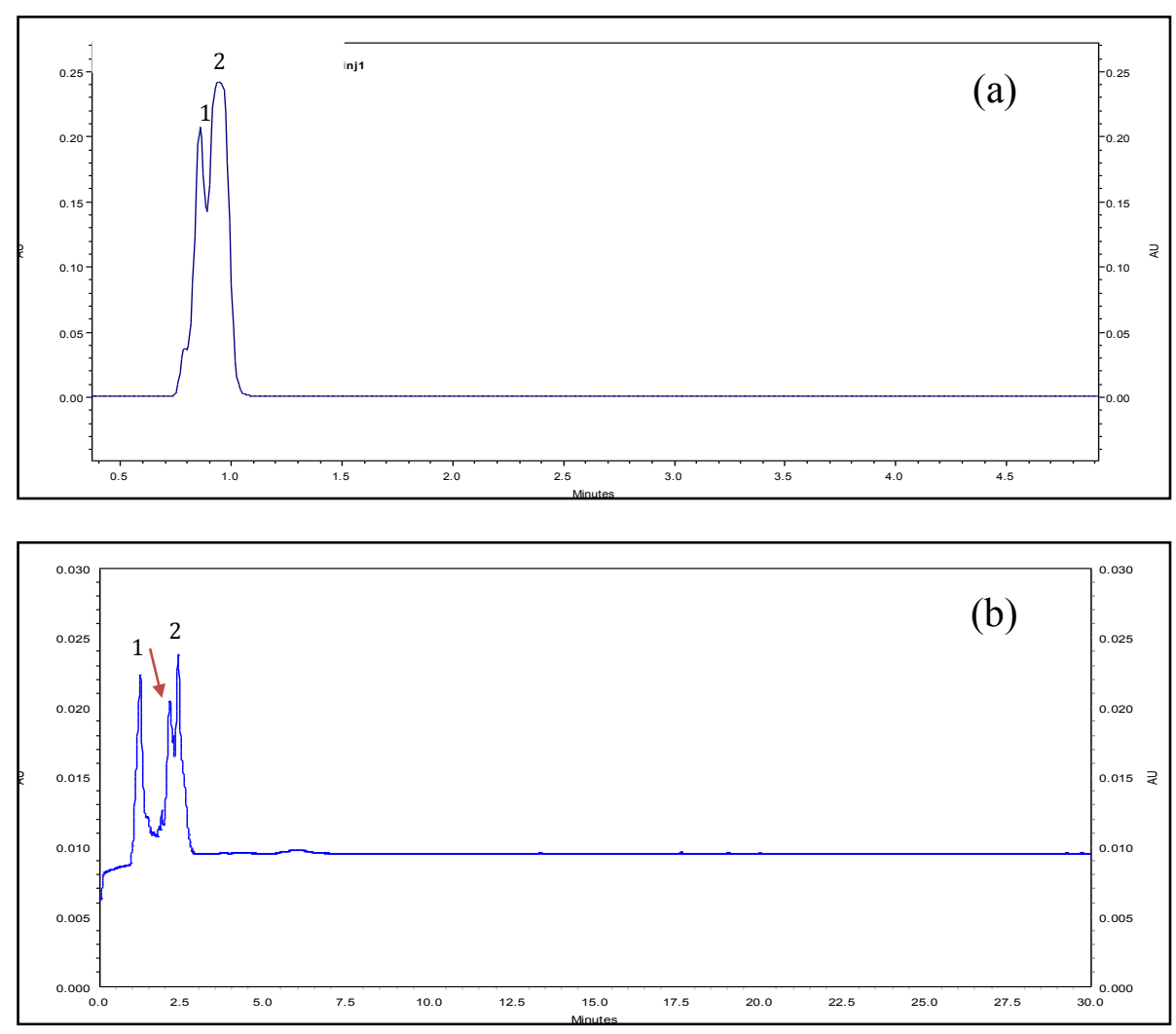


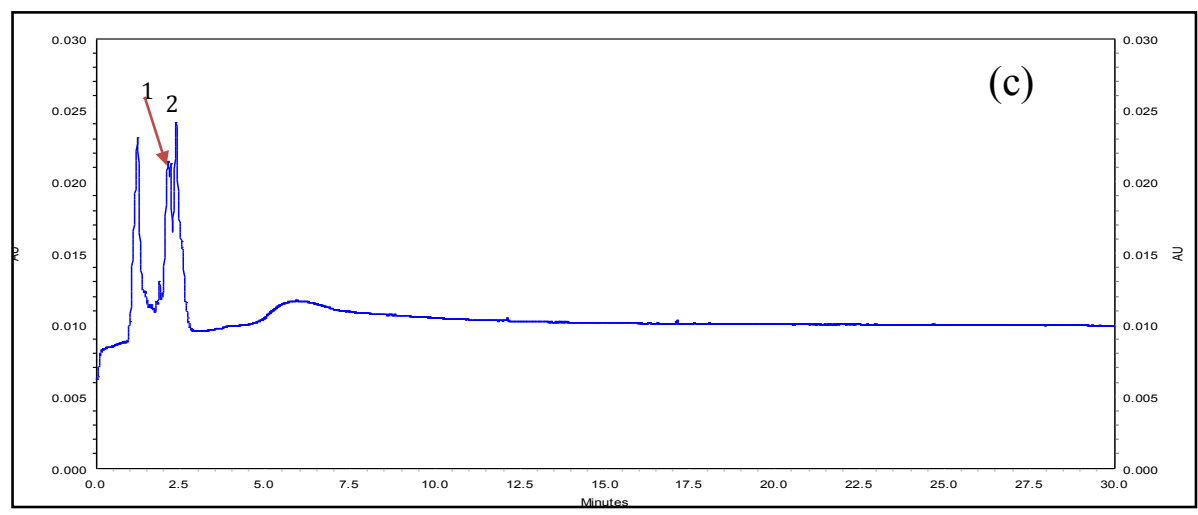

Figure 8. CE-UV electropherograms of lipopolysaccharides from Gram-negative bacteria (A) 055:B5; (B) EToxate ${ }^{\mathrm{TM}}$; (C) Klebsiella pneumoniae. Running buffer: $\mathrm{SDS} / \mathrm{Na}_{2} \mathrm{~B}_{4} \mathrm{O}_{7}(40 \mathrm{mM} / 10 \mathrm{mM}$, pH 9.22). Applied voltage $=30 \mathrm{kV}$; injection time $=5 \mathrm{~s}$. Capillary dimensions are indicated in experimental section

With the buffering system optimized using SDS/ $\mathrm{Na}_{2} \mathrm{~B}_{4} \mathrm{O}_{7}(40 \mathrm{mM} / 10 \mathrm{mM}, \mathrm{pH} 9.22)$, LPS from E. coli 055:B5, $E$. coli K-235 and Klebsiella pneumonia were analyzed using the same conditions as in the experimental section, and their migration times, peak heights, and peak areas were determined. Each LPS analysis was conducted in triplicates and the results are summarized in Table 2 and Figure 9. The representative electropherograms from these three LPS also indicate the distinct similarity using CE-UV profiling, as shown in Figure 10. Each showing three prominent signals, with the first peak appearing at 1.30 minute, and an overlapping twin peaks at around $2.08( \pm 0.28)$ minutes, as shown in an enlarged scale in Figure 11.

The apparent data generated for each variant peak showed very good precision for migration time with percentage RSD values of $\leq 1.2 \%(n=3)$. Similarly, the percentage RSD for peak area values are $\leq 5.3 \%(n=3)$ across different LPS.

Table 2. Summary of data from electropherograms across three LPS types (concentration $=5.0 \mathrm{mg} / \mathrm{mL}$ in BGE)

\begin{tabular}{|c|c|c|c|c|c|c|c|}
\hline & \multirow[b]{2}{*}{ Sample } & \multicolumn{3}{|c|}{ Peak 1} & \multicolumn{3}{|c|}{ Peak 2} \\
\hline & & $\begin{array}{c}\text { Migration } \\
\text { Time } \\
\text { (minutes) }\end{array}$ & $\begin{array}{c}\text { Peak } \\
\text { Height } \\
\text { (mAU) }\end{array}$ & $\begin{array}{l}\text { Peak } \\
\text { Area }\end{array}$ & $\begin{array}{c}\text { Migration } \\
\text { Time } \\
\text { (minutes) }\end{array}$ & $\begin{array}{c}\text { Peak } \\
\text { Height } \\
\text { (mAU) }\end{array}$ & $\begin{array}{c}\text { Average } \\
\text { Peak } \\
\text { Area }\end{array}$ \\
\hline \multirow{5}{*}{$\begin{array}{ll}E . & \text { coli } \\
055: \mathrm{B} 5\end{array}$} & 1 & 2.12 & 14.1 & 48854 & 2.40 & 17.7 & \multirow{4}{*}{90417} \\
\hline & 2 & 2.13 & 14.1 & 45717 & 2.39 & 17.8 & \\
\hline & 3 & 2.12 & 14.1 & 48221 & 2.38 & 17.4 & \\
\hline & Average & 2.12 & 14.1 & 47597 & 2.39 & 17.6 & \\
\hline & RSD (\%) & 0.2 & 0.2 & 3.5 & 0.2 & 1.1 & 2.9 \\
\hline \multirow{5}{*}{$\begin{array}{l}\text { Klebsiella } \\
\text { pneumoniae }\end{array}$} & 1 & 2.11 & 19.1 & 67284 & 2.36 & 17.8 & \multirow{4}{*}{75161} \\
\hline & 2 & 2.14 & 19.2 & 73162 & 2.33 & 18.1 & \\
\hline & 3 & 2.10 & 21.8 & 68765 & 2.30 & 18.1 & \\
\hline & Average & 2.12 & 20.0 & 69737 & 2.33 & 18.0 & \\
\hline & RSD (\%) & 1.0 & 7.7 & 4.4 & 1.2 & 1.1 & 5.3 \\
\hline \multirow{5}{*}{$\begin{array}{l}\text { E. coli } \\
\text { K-235 }\end{array}$} & 1 & 1.87 & 17.6 & 87752 & 2.37 & 10.0 & \multirow{4}{*}{60915} \\
\hline & 2 & 1.85 & 18.1 & 87455 & 2.34 & 10.1 & \\
\hline & 3 & 1.83 & 18.5 & 84463 & 2.32 & 10.1 & \\
\hline & Average & 1.85 & 18.1 & 86556 & 2.34 & 10.0 & \\
\hline & RSD (\%) & 0.9 & 2.5 & 2.1 & 1.1 & 0.5 & 2.6 \\
\hline
\end{tabular}



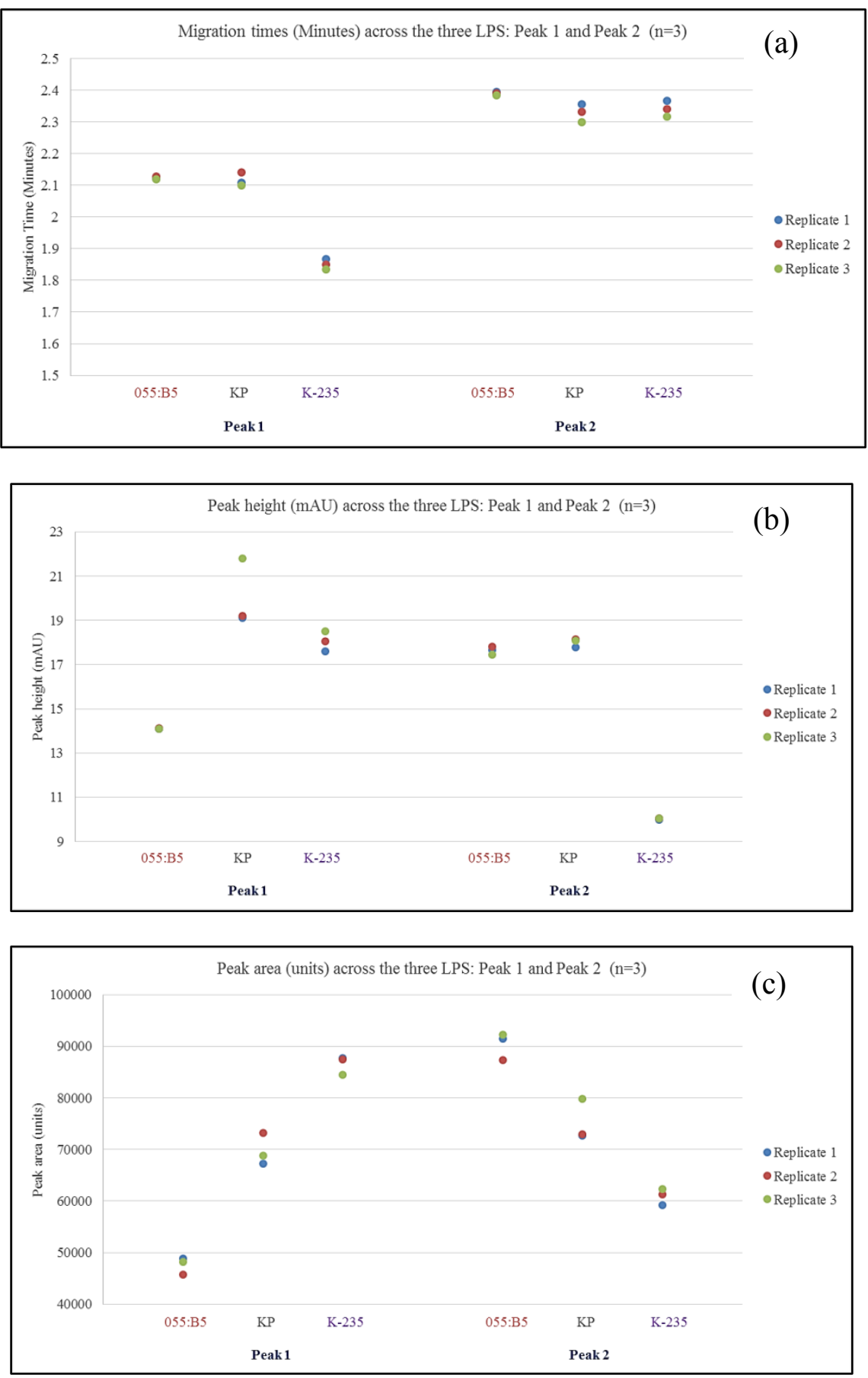

Figure 9. Graphical representation of the reproducibility of the electropherogram peaks of the three LPS analyzed by direct CE-UV detection (A) migration time; (B) peak height; (C) peak area. Running buffer: $\mathrm{SDS} / \mathrm{Na}_{2} \mathrm{~B}_{4} \mathrm{O}_{7}(40 \mathrm{mM} / 10 \mathrm{mM}, \mathrm{pH} 9.22)$. Applied voltage $=30 \mathrm{kV}$; injection time $=5 \mathrm{~s}$. Capillary dimensions are indicated in experimental section. Legend: 055:B5 (E. coli 055:B5); KP (Klebsiella pneumoniae); K-235 (E. coli K-235) 
Fung et al: EFFECT OF BUFFER COMPOSITION ON THE ANALYSIS OF LIPOPOLYSACCHARIDES

FROM Escherichia coli 055:B5 AND UT189 BY CAPILLARY ELECTROPHORESIS WITH

DIRECT UV DETECTION

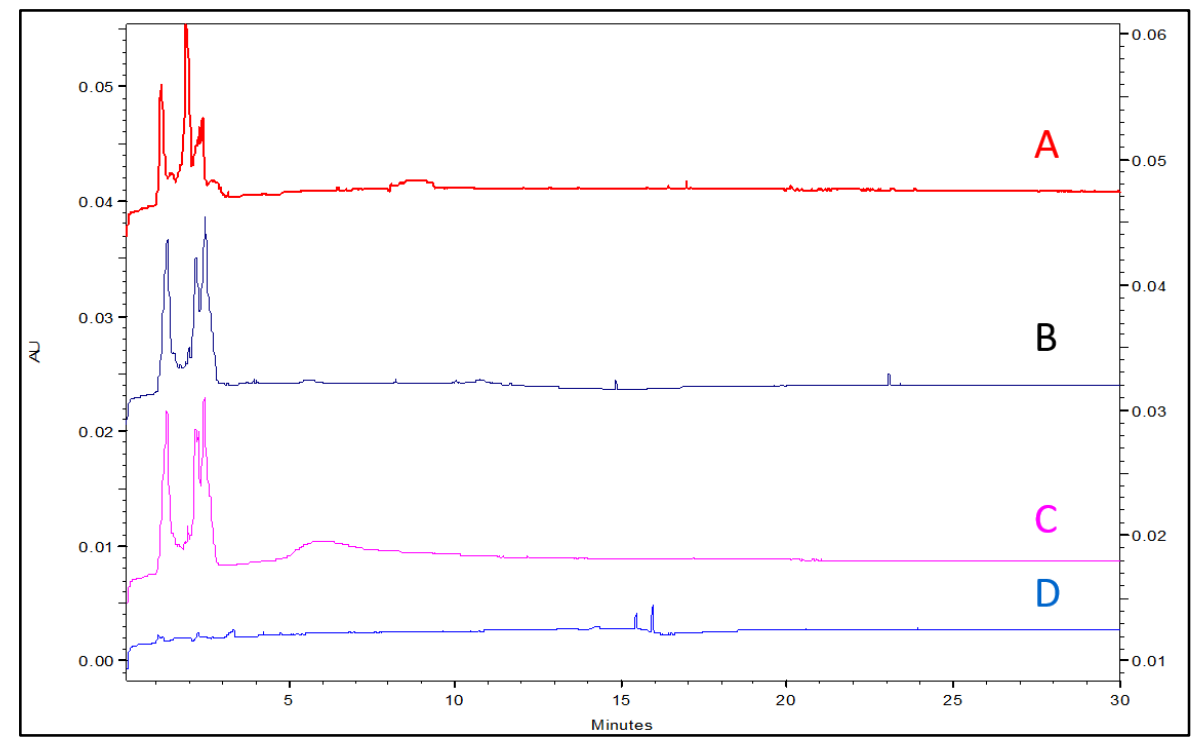

Figure 10. CE-UV electropherograms of lipopolysaccharides from Gram-negative bacteria (A) K-235; (B) 055:B5; (C) Klebsiella pneumoniae; (D) Blank buffer. Running buffer: SDS/ $\mathrm{Na}_{2} \mathrm{~B}_{4} \mathrm{O}_{7}(40 \mathrm{mM} / 10 \mathrm{mM}, \mathrm{pH}$ 9.22). Applied voltage $=30 \mathrm{kV}$; injection time $=5 \mathrm{~s}$. Capillary dimensions are indicated in experimental section

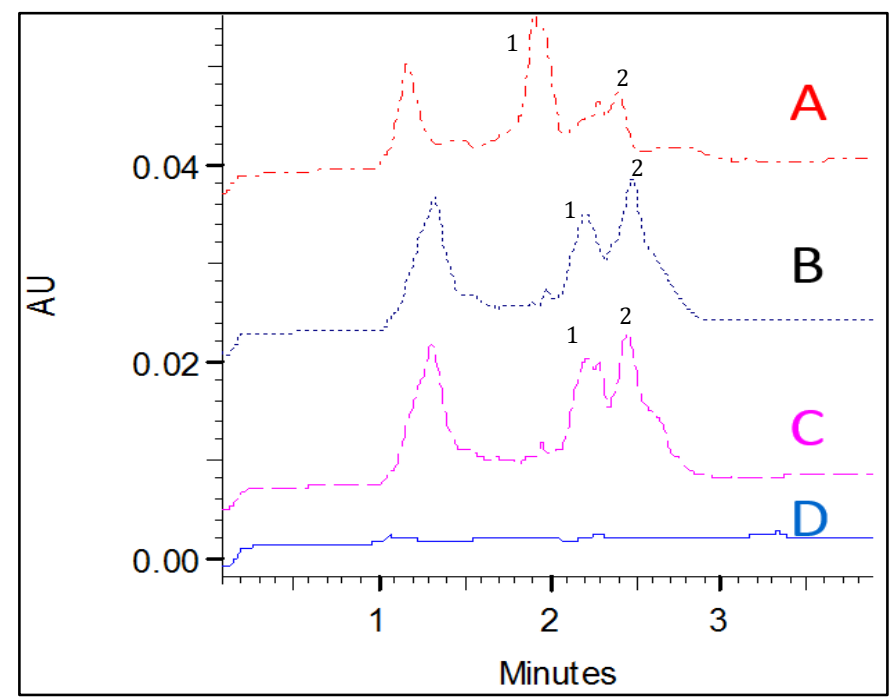

Figure 11. Enlarged electropherograms in the region from 0 to 4 minutes of Figure 10, CE-UV electropherograms of lipopolysaccharides from Gram-negative bacteria (A) K-235; (B) 055:B5; (C) Klebsiella pneumoniae; (D) Blank buffer. Running buffer: $\mathrm{SDS} / \mathrm{Na}_{2} \mathrm{~B}_{4} \mathrm{O}_{7}(40 \mathrm{mM} / 10 \mathrm{mM}$, pH 9.22). Applied voltage $=30 \mathrm{kV}$; injection time $=5 \mathrm{~s}$. Capillary dimensions are indicated in experimental section

\section{Conclusion}

Optimization of the electrophoresis buffer was carried out for capillary electrophoresis-direct UV analysis of LPS from E. coli 055:B5, K-235, UT189, E-Toxate ${ }^{\mathrm{TM}}$, and Gram-negative bacteria Klebsiella pneumoniae. We have demonstrated three buffer systems that could provide consistent detectable signals for the separation of LPS. They are (i) Tris/Borate/EDTA (445 mM/445 mM/10 mM); (ii) SDS/ $\mathrm{Na}_{2} \mathrm{~B}_{4} \mathrm{O}_{7}\left(40 \mathrm{mM} / 10 \mathrm{mM}\right.$ ); (iii) $\mathrm{Na}_{2} \mathrm{~B}_{4} \mathrm{O}_{7} / \mathrm{DAB}$ (50 $\mathrm{mM} / 10 \mathrm{mM})$. Reproducible electropherograms using the buffering system consisting of $\mathrm{SDS} / \mathrm{Na}_{2} \mathrm{~B}_{4} \mathrm{O}_{7}(40 \mathrm{mM} / 10$ 
$\mathrm{mM}, \mathrm{pH}$ 9.22) were obtained for LPS from E. coli 055:B5, K-235 and Gram-negative bacteria Klebsiella pneumonia, with percentage RSD values of migration time $\leq 1.2 \%(\mathrm{n}=3)$. The percentage RSD values for peak area are $\leq 5.3 \%(\mathrm{n}=3)$ across different LPS. The optimized buffer system could provide potentially quantitative and qualitative analyzes of these LPS using capillary electrophoresis with direct UV detection.

\section{Acknowledgement}

This research grant (Grant number 1301-IRIS-026) is supported by the Singapore National Research Foundation under its Environment \& Water Research Programme and administered by PUB, Singapore's National Water Agency.

\section{References}

1. Ramachandran, G. (2014). Gram-positive and gram-negative bacterial toxins in sepsis: A brief review. Virulence, 5(1): $213-218$.

2. Laitinen, S., Kangas, J., Kotimaa, M., Liesivuori, J., Martikainen, P. J., Nevalainen, A., Sarantila, R. and Husman, K. (1994). Workers' exposure to airborne bacteria and endotoxins at industrial wastewater treatment plants. American Industrial Hygiene Association, 55(11): 1055 - 1060.

3. Jorgensen, J. H., Lee, J. C. and Pahren, H. R. (1976). Rapid detection of bacterial endotoxins in drinking water and renovated wastewater. Applied and Environmental Microbiology, 32(3): 347 - 351.

4. Kastowsky, M., Gutberlet, T. and Bradaczek, H. (1992). Molecular modelling of the three-dimensional structure and conformational flexibility of bacterial lipopolysaccharide. Journal of Bacteriology, 174(14): 4798 $-4806$.

5. Silhavy, T. J., Kahne, D. and Walker, S. (2010). The bacterial cell envelope. Cold Spring Harbor Perspectives in Biology, 2(5): 1 - 16.

6. Kilár, A., Dörnyei, Á. and Kocsis, B. (2013). Structural characterization of bacterial lipopolysaccharides with mass spectrometry and on-and off-line separation techniques. Mass Spectrometry Reviews, 32(2): 90 - 117.

7. Lamari, F. N., Gioldassi, X. M., Mitropoulou, T. N. and Karamanos, N. K. (2002). Structure analysis of lipoglycans and lipoglycan-derived carbohydrates by capillary electrophoresis and mass spectrometry. Biomedical Chromatography, 16(2): 116 - 126.

8. Volpi, N., Maccari, F. and Linhardt, R. J. (2008). Capillary electrophoresis of complex natural polysaccharides. Electrophoresis, 29(15): 3095 - 3106.

9. Restaino, O. F., Cimini, D., De Rosa, M., De Castro, C., Parrilli, M. and Schiraldi, C. (2009). Highperformance CE of Escherichia coli K4 cell surface polysaccharides. Electrophoresis, 30(22): 3877 - 3883.

10. Volpi, N. (2003). Separation of Escherichia coli 055: B5 lipopolysaccharide and detoxified lipopolysaccharide by high-performance capillary electrophoresis. Electrophoresis, 24(17): $3097-3103$.

11. Eugene, C. Y. and Hackett, M. (2000). Rapid isolation method for lipopolysaccharide and lipid A from gramnegative bacteria. Analyst, 125(4): $651-656$.

12. Lan, M., Wu, J., Liu, W., Zhang, W., Ge, J., Zhang, H., Sun, J., Zhao, W. and Wang, P. (2012). Copolythiophene-derived colorimetric and fluorometric sensor for visually supersensitive determination of lipopolysaccharide. Journal of the American Chemical Society, 134(15): 6685 - 6694.

13. Wu, S. F., Chiu, T. C., Ho, W. L. and Chang, H. T. (2009). Combining capillary electrophoresis with laserinduced fluorescence detection for the analysis of Escherichia coli lysates. Electrophoresis, 30(13): 2397 2402.

14. Wenz, C., Marchetti-Deschmann, M., Herwig, E., Schröttner, E., Allmaier, G., Trojer, L., Vollmer, M. and Rüfer, A. (2010). A fluorescent derivatization method of proteins for the detection of low-level impurities by microchip capillary gel electrophoresis. Electrophoresis, 31(4): $611-617$.

15. Volpi, N. (2004). Separation of capsular polysaccharide K4 and defructosylated K4 by high-performance capillary electrophoresis. Electrophoresis, 25(4-5): $692-696$.

16. Knudsen, C. B. and Beattie, J. H. (1997). On-line solid-phase extraction-capillary electrophoresis for enhanced detection sensitivity and selectivity: application to the analysis of metallothionein isoforms in sheep fetal liver. Journal of Chromatography A, 792(1): $463-473$.

17. Westphal, O. and Lüderitz, O. (1954). Chemische erforschung von lipopolysacchariden gramnegativer bakterien. Angewandte Chemie, 66(13-14): 407 - 417. 
Fung et al: EFFECT OF BUFFER COMPOSITION ON THE ANALYSIS OF LIPOPOLYSACCHARIDES

FROM Escherichia coli 055:B5 AND UT189 BY CAPILLARY ELECTROPHORESIS WITH

DIRECT UV DETECTION

18. Yu, L., Yuan, L., Feng, H. and Li, S. F. Y. (2004). Determination of the bacterial pathogen Edwardsiella tarda in fish species by capillary electrophoresis with blue light-emitting diode-induced fluorescence. Electrophoresis, 25(18-19): 3139 - 3144.

19. Venter, P. and Lues, J. F. R. (2003). Extraction methods for lipopolysaccharides from Escherichia coli ATCC 25922 for quantitative analysis by capillary electrophoresis. International Journal of Food Microbiology, 84(2): $245-250$.

20. Giordano, B. C., Muza, M., Trout, A. and Landers, J. P. (2000). Dynamically-coated capillaries allow for capillary electrophoretic resolution of transferrin sialoforms via direct analysis of human serum. Journal of Chromatography B: Biomedical Sciences and Applications, 742(1): 79 - 89. 